ASIAN JOURNAL OF MANAGEMENT STUDIES

Journal homepage: https://www.sab.ac.lk/ajms/

Faculty of Management Studies Sabaragamuwa University of Sri Lanka

\title{
Determinants of Adoption of Cloud-based Accounting: A Paradigm Shift in Sri Lanka
}

\author{
Dulmini S. Premarathne ${ }^{1}$, Nadarajah Rajeshwaran ${ }^{2}$, and Epitawalage K. \\ Umayangana $^{3}$ \\ ${ }^{1,2,3}$ Department of Commerce, Faculty of Commerce and Management, Eastern University, \\ Sri Lanka
}

\begin{abstract}
Cloud-Based Accounting (CBA) transforms the accounting system into a sophisticated platform in a turbulent environment. Factors behind the adoption of the CBA are still scepticism. Therefore, the study mainly aims to examine perceived determinants of the adoption of Cloud-Based Accounting (CBA) in Sri Lanka. Human, technological, organisational, and environmental factors are used as independent variables for identifying the determinants of CBA. Data were collected from two hundred professional accountants by using a questionnaire. Descriptive statistics, correlation, and multiple regression were applied to analyse the collected data. The results show that the above four factors are at a high level, and they significantly and positively impact the adoption of CBA. The study provides insights into the policymakers to better understand and enable them to implement suitable strategies to minimise potential damaging factors and improve current trends in their development.
\end{abstract}

Keywords: Cloud Computing, Environment, Human, Organisation, Sri Lanka, Technological-Fit
(C) Faculty of Management Studies Sabaragamuwa University of Sri Lanka

ARTICLE INFO Article history: Received: 12 December 2020 Accepted: 20 January 2021 Published: 09 February 2021 


\section{INTRODUCTION}

Cloud computing had attracted considerable attention from the information technology (IT) industry since the term was coined in 2008. Described as a paradigm-shifting innovation, cloud computing brings together different pieces of technology and computing resources to create a coherent ecosystem over the internet. It allows users to store data and use applications through different devices located in several locations (Buyya et al., 2008). After the deployment of cloud computing in different types of businesses, at a certain point, it has also reached the accounting field. Sharma (2016) pointed out that there are numerous studies on cloud computing technology that were embraced in the adoption of cloud computing technology by businesses and its related costs, benefits, advanced security and privacy issues, measures for security solutions, and reasonableness with technology are analysed regarding cloud computing. However, very few investigations have been done in the field of cloud accounting and its future perspectives; it is the most rising and immaculate area in the field of accounting.

Cloud accounting includes the use of software for the accumulation and processing of information through the Internet-based cloud supplier's applications. In this manner, the accounting software and information are located on the remote server, software establishment and support on individual computers are a bit much, and information "retrieval" by an enormous number of clients is at the same time conceivable at any minute from countless devices. Significant benefits of cloud accounting, in contrast with traditional accounting, also result from the use of software as a service (SaaS) assistance given by the cloud supplier, as opposed to software introduced on the client's computer (Dimitriua \& Mateia, 2015). Traditional accounting software is generally secured as "tangible" assets and installed on the client's computer system, while with the cloud, the client buys the right to use the software via the internet. Thus, Cloud accounting solutions are transforming how accounting applications are used, and they are modernising the entire business environment. Cloud technology application has changed the function of accounting concerning the use of traditional software.

Cloud accounting gives the accountant instant and mobile access to clients' financial information. Although it is completely changing the way accountants work, the accounting profession is being polarised in respect of cloud technology. According to Rao et al. (2012), the emerging trends in 
accounting not only help in increasing the effectiveness of the firms but also provide an extra cost-benefit. In such a case, there is a need to study whether the perceived benefits are actually enjoyed by the firms which are incorporating these trends into business.

The accounting process would be quicker and more effective in the introduction of cloud accounting. It empowers access to truthful and real-time information, which consequently expands the transparency of financial information revealed through cloud platforms. However, security and protection of customer financial information, susceptibility to authorised access are the main risk of using cloud accounting (Dimitriua \& Mateia, 2015).

According to Christaukas and Miseviciene (2012), small and mediumsized companies do not always have the chance to utilise professional services in the IT sector. Finance is the main limiting factor. Maintenance of high quality and expertly arranged, steady, and custom-fitted to the work servers is costly. Procurement of all the software necessary, especially for the small business entity, is very complicated and expensive. Local market-specific accounting programs are also costly; they are having problems in installing open-source operating systems such as Linux. There are other unexpected issues, particularly when the computer crashers.

Geographically unlimited access through remote network access was considered as the most important benefit, whereas the non-coverage of information security in legal terms is considered as the most endangering risk faced by the accountants if they move into the cloud. The most important barrier that hinders the adoption process of cloud accounting was the lack of awareness about cloud accounting (Livera, 2017).

Bangladesh, one of the N-11 countries, studied the adoption of a cloud accounting system for encouraging startups, generating employment, and protecting the environment (Sobhan, 2019). Ebenezer and Antwi (2014) has conducted a study emphasising the importance of cloud accounting in the business sector of Ghana. A study was conducted by Waga et al. (2014) on the implementation of cloud computing in the educational sector of Kenya. The study conducted by Mizuno and Odake (2015) clarifies the best practice of an accounting cloud service in Japan, which has two-sided markets and freemium structure, and how to formulate its service. Albeit most of the research studies relating to the adoption of Cloud-Based Accounting are in the Asia region, 
cloud accounting has not increased enough fame among organisations in the context of Sri Lanka.

Most empirical evidence comes from other countries. But there seems to be a lack of evidence in an emerging country, particularly Sri Lanka. Therefore, the study tries to find the answer to the following research question "What are the factors influencing the adoption of Cloud-Based Accounting in Sri Lanka?" As stated in the research problem, this research intends to examine the influence of human, technological, organisational, and environmental factors on the adoption of Cloud-Based Accounting in Sri Lanka.

The remaining part of the paper covers an overview of the literature and methodology. Consequently, the results of the study presented with discussion. Finally, conclusions and recommendations are given.

\section{LITERATURE REVIEW}

\section{Cloud Computing}

The dawn of the internet brought technological changes at a more rapid pace than previous, and businesses and consumers have witnessed these technological changes in the past two decades. As early risers, relatively young companies such as Google, Amazon, and Facebook have considered taking such technologies deeply within their business models (Strauss et al., 2014). In today's competitive marketplace, customer experience is fundamental, and cloud computing is a proven means to ensure a high level of service. "Cloud" has remodelled the way that people and institutions collaborate, communicate, share and store information and the manner that they obtain Information Technology resources or services for their personal and professional use (Dimitriua \& Mateia, 2015). At the structure of cloud computing is the wider idea of converged facilities and also common solutions Cloud computing, or simply "the cloud", additionally concentrates on optimising the performance of the shared sources (Bhandayker, 2019).

\section{Concept of Cloud-Based Accounting}

Cloud accounting or online accounting acts like accounting applications installed on users' computers, but it is performed on servers offering online services, and uses can access them through web browsers (Dimitriua \& Mateia, 2015). According to Dimitriua and Mateia (2015), the world of 
bookkeeping is shifting towards online products. Due to the emergence of accounting software, the practice of accounting has improved immensely. Cloud accounting has emerged convergence of the basic principles of cloud computing and activities carried out by accounting software companies. The accountants must develop insights into these factors that will ultimately reshape the future of organisations. This says the importance of evaluating the effects of the changes in the entire accounting system covering standards, processes, and accounting staff. The content of financial reporting standards would be changed to reflect the changes that occur due to cloud-based accounting (Dimitriua \& Mateia, 2015).

Livera (2017) stated that the definition of cloud accounting has not yet been established, but certain authors have described it as merging cloud computing and accounting principles. "Cloud accounting or online accounting" acts like accounting applications installed on users' computers, but it is performed on servers offering online services, and uses can access them through web browsers.

According to Mihalache (2011), Cloud accounting is defined as a modern concept in computer processing of accounting data based on the concept of cloud computing, which represents a set of distributed computing services, applications, access to information, and data storage without the user having to know the physical location and configuration of systems providing these services. Cloud accounting solutions possess the ability to transform how accounting applications are used by accountants and thus modernise the entire business world. What differentiates cloud accounting from the traditional way of accounting is that it can demonstrate the current financial state of business as the statements could be prepared on a real-time basis (Dimitriua \& Mateia, 2015).

As far as the researcher has understood by reviewing the current literature is that, cloud computing is the next generation of computing, and it has extended its assistance to a wider range of stakeholders through its features. Cloud accounting can be called an extension of cloud computing, as the cloud accounting paradigm is a combination of cloud computing principles and accounting practices. Studies prove that cloud accounting is gaining momentum in recent days, but this has not gained the attention of local researchers. 


\section{Theories Relating to the Adoption of Cloud-Based Accounting}

\section{Innovation Diffusion Theory}

According to Shy (1997), innovation diffusion theory postulates five characteristics of innovations that are affecting their diffusion. Those characteristics are a relative advantage (the extent to which technology offers improvements over currently available tools), compatibility (its consistency with social practices and norms among its users), complexity (its ease of use or learning), trial-ability (the opportunity to try an innovation before committing to use it), and observability (the extent to which the technology's outputs and its gains are clear to see). Diffusion studies have demonstrated that innovations affording advantages, compatibility with existing practices and beliefs, low complexity, potential trial-ability, and observability will be more extensively and rapidly diffused than innovation with the cluster of opposite characteristics (Dandago \& Rufai, 2014, p.658). Accordingly, it can be identified that two qualities of AIS, which are system quality (relative advantage, complexity, and trial-ability) and information quality (compatibility and observability), are delineating in the Innovation Diffusion Theory. The innovation diffusion theory is as an underlying subject matter of accounting information system on reporting quality (Robert \& Agada, 2016).

Rogers (2003) stated that the word "technology" and "innovation" are synonyms. For Rogers (2003), "a technology is a design for instrumental action that reduces the uncertainty in the cause-effect relationships involved in achieving the desired outcome." Rogers (2003) defines diffusion as "the process in which an innovation is communicated through certain channels over time among the members of a social system." As expressed in this definition, innovation, communication channels, time, and social system are the four key components of the diffusion of innovations. Rogers (2003) described the innovation-decision process as "an information-seeking and informationprocessing activity, where an individual is motivated to reduce uncertainty about the advantages and disadvantages of an innovation." The innovationdecision process involves five steps: (1) knowledge, (2) persuasion, (3) decision, (4) implementation, and (5) confirmation.

The researcher can identify the elected factors that might influence the adoption of cloud-based accounting using quantitative research methods and Roger's diffusion theory. For instance, Isleem (2003) examined the level of 
computer use for instructional purposes by technology education teachers in Ohio public schools. Medlin (2001) used the diffusion of innovations theory to examine the selected factors that might influence a faculty member's motivation and decision to adopt new electronic technologies in classroom instruction.

\section{Theory of Reasoned Action}

In 1980, Ajzen and Fishbein found the theory of reasoned action. They formulated the theory after trying to estimate the discrepancy between attitude and behaviour. The fundamentals of the theory have come from the field of social psychology. Social psychologists attempt to explain how and why attitude affects behaviour. That is, how and why people's beliefs change the way they act. The theory has three general constructs: (1) behavioural intention, (2) attitude, and (3) subjective norm.

Ajzen and Fishbein (1980) suggested that a person's behaviour is determined by the person's intention to perform the behaviour and that this intention is, in turn, a function of the person's attitude toward the behaviour. One of the potential reflectors of possible behavioural outcomes is intention. One might have the belief that adopting modern ICT is good for one's professional career. It enhances efficiency and also effectiveness. However, it is time-consuming to learn, and resources are also not always available. Each of these beliefs can be weighted based on one's perception of the merits of those beliefs.

According to Shareef et al. (2009), the theory of reasoned action conjectures that behavioural intention is the most influential predictor of behaviour. This model has been developed to provide parsimonious explanations of informational and motivational influences on behaviour. It can also be considered as a deliberative processing model, as it implies that individuals make behavioural decisions based on careful consideration of available information.

\section{Models for Cloud-Based Accounting}

\section{Fit of Human, Organisation and Technology Factors}

The human, organisation, and technology-fit (HOT-fit) framework was developed through a comprehensive and extensive model validation in the 
field of innovation. The model addresses categories of the human, organisation, and technology factors and interrelated dimensions and points out that a mutual alignment will more likely ensure successful adoption and implementation (DeLone \& McLean, 2003).

\section{Technology-Organisation-Environment (TOE) Framework}

TOE is one of the most widely used adoption theories, operating at the organisation level. It holistically models how the three major contexts: technology, organisation, and environment influence innovation adoption and implementation. In the TOE framework, the technological context relates to both internal and external technologies available to an organisation. Its main focus is on how the existing technologies within the organisation, as well as the available innovations external to the firm influence the innovation adoption process. The organisational context describes the impact of the characteristics of firms on the innovation adoption process. Common organisation characteristics include firm size, degree of centralisation and formalisation, the complexity of its management structure, the quality of its human resources, and the number of slack resources. Lastly, the environmental context is the field where an organisation runs its business; the industry, competitors, and government regulation define the environmental context.

Abdullah (2016) has identified that a high level of IT capability of staff in the study of CBA adoption and top management support. And also, competitive pressure shows a high level. Gutierrez et al. (2015) also found complexity is a significant factor in the adoption decision, in contrast to other innovation characteristics. Tehrani (2013) defined complexity as a negative impact on the decision-making process in cloud adoption. There is a significant positive relationship between the training of employees in adopting organisations and the propensity with which technologies are adopted (Warren, 2004).

According to the findings of Qirim (2008), it has proved that CBA adoption is positively related to the innovativeness of senior executives. There is a positive, significant relationship between training of employees in adopting organisations and the propensity with which technologies are adopted (Warren, 2004). Sobhan (2019) confirmed that complexity has found a negative relationship with CBA adoption and compatibility shows a positive relationship. According to the findings of Malak (2016), compatibility showed 
significant positive associations between the adoption of new technologies. Sharif (2015) also found a high level of compatibility positively motivates the organisation to adopt Information systems.

\section{Hypotheses Formulation}

Based on the previous researchers' arguments, Fit of Human, Organisation and Technology Factors, Technology-OrganisationEnvironment Framework, and considering Innovation Diffusion Theory and Theory of Reasoned Action, the following hypotheses are formulated.

$\mathrm{H}_{1}$ : Innovativeness of Senior Executive significantly impacts the adoption of Cloud-Based Accounting.

$\mathrm{H}_{2}$ : IT capability of staff significantly impacts the adoption of Cloud-Based Accounting.

$\mathrm{H}_{3}$ : IT Infrastructure significantly impacts the adoption of Cloud-Based Accounting.

$\mathrm{H}_{4}$ : Compatibility significantly impacts the adoption of Cloud-Based Accounting.

$\mathrm{H}_{5}$ : Complexity significantly impacts the adoption of Cloud-Based Accounting.

$\mathrm{H}_{6}$ : Perceived value significantly impacts the adoption of Cloud-Based Accounting.

$\mathrm{H}_{7}$ : Relative advantage significantly impacts the adoption of Cloud-Based Accounting.

$\mathrm{H}_{8}$ : Top management support significantly impacts the adoption of CloudBased Accounting.

$\mathrm{H}_{9}$ : Perceived cost significantly impacts the adoption of Cloud-Based Accounting.

$\mathrm{H}_{10}$ : Competitive Pressure significantly impacts the adoption of Cloud-Based Accounting. 


\section{METHODOLOGY}

A population is a complete set of people with a specialised set of characteristics that process the information sought by the researcher (Banerjee $\&$ Chaudhury, 2010). The population of the research identified as accountants who are possessing either a professional or/and academic qualification and work as accountants in Sri Lanka. Accountants in business are diverse, occupied in commerce, industry, financial services, education, and the public and not profit sectors as employees and advisers. They are expertise very well to the technological developments that have taken place in the profession. Therefore, accountants are chosen as the population.

Snowball sampling method is applied when it is challenging to access subjects with target characteristics. In this method, the existing study subjects recruit future subjects between their acquaintances. Due to unawareness about the exact population and without having a direct conversation with accountants, this method was used for data collection. This sampling method involves a primary data source nominating other potential data sources that will be able to participate in the research studies. Snowball sampling method is purely based on referrals, and that is how a researcher can generate a sample. Therefore, this method is also called the chain-referral sampling method. In this research study, the sample size was taken as 200 accountants in Sri Lanka using this chain referral sampling technique.

The previous studies of Alam et al. (2016) and Awa et al. (2016) were used to developed the questionnaire and distributed it among the accountants in Sri Lanka as google forms. Responses were received around 230, and the sample was taken as 200 accountants rejecting some of the respondents due to some filling errors. The survey approach was appropriated for this study because of the nature of the constructs presented in the theoretical model. There were two types of data used in the research study as primary data and secondary data.

The variables in the research model (human factors, technological factors, organisational factors, environmental factors, and CBA adoption) were measured through questionnaires with five-point Likert scale and demographic factors measured through the nominal scale, which were completed by the respondents. 
Every variable in the research model was analysed using descriptive statistics (mean and standard deviation values). Decision criteria are as follows.

Table 1: Decision Rule

\begin{tabular}{|c|c|}
\hline Decision Criteria & Decision Attributes \\
\hline $1.0 \leq X \leq 2.5$ & $\begin{array}{l}\text { Low level in Human, Technological, Organisational, and } \\
\text { Environmental factors }\end{array}$ \\
\hline $2.5<X \leq 3.5$ & $\begin{array}{l}\text { Moderate level in Human, Technological, Organisational, and } \\
\text { Environmental factors }\end{array}$ \\
\hline $3.5<X \leq 5$ & $\begin{array}{l}\text { High level in Human, Technological, Organisational, and } \\
\text { environmental factors }\end{array}$ \\
\hline
\end{tabular}

Source: Developed by researchers

Correlation analysis and multiple regression were applied for regression models with one dependent variable and more than one independent variable.

\section{RESULTS AND DISCUSSION}

Table 2 depicts the distribution of responses throughout the personal information. Eight personal factors as Gender, Age Level, Academic Qualifications, Professional Qualifications, Employed Sector, Current Level of Employment, Years of Experience, and Accounting System Currently Use are used for this study. The majority of the respondents are males and under the age of 31-40. The least number of respondents are under the category of age above 50. Most of the respondents are qualified with a degree while completing ICASL. The majority of accountants are working in the finance sector and middle-level of employment. Most of the accountant have 6-10 years of work experience, and they are using commonly using Quickbook as their main accounting system. 
Table 2: Personal Information

\begin{tabular}{|c|c|}
\hline Classification & $\begin{array}{c}\text { No. of } \\
\text { Respondents }\end{array}$ \\
\hline \multicolumn{2}{|l|}{ Gender } \\
\hline Male & 143 \\
\hline Female & 57 \\
\hline \multicolumn{2}{|l|}{ Age Level } \\
\hline $21-30$ & 67 \\
\hline $31-40$ & 93 \\
\hline $41-50$ & 36 \\
\hline Above 50 & 4 \\
\hline \multicolumn{2}{|l|}{ Academic Qualifications } \\
\hline GCE A/L & 40 \\
\hline Certificate/ Diploma & 28 \\
\hline Degree & 98 \\
\hline Postgraduate Diploma & 16 \\
\hline MBA/ M.Sc. & 17 \\
\hline $\mathrm{Ph} . \mathrm{D}$ & 1 \\
\hline \multicolumn{2}{|l|}{ Professional Qualifications } \\
\hline ICASL & 54 \\
\hline CMA & 37 \\
\hline ACCA & 16 \\
\hline AAT & 61 \\
\hline CIMA & 23 \\
\hline Other & 9 \\
\hline \multicolumn{2}{|l|}{ Employed Sector } \\
\hline Audit Firms & 33 \\
\hline Manufacturing & 57 \\
\hline Finance & 86 \\
\hline Other & 24 \\
\hline \multicolumn{2}{|l|}{ Current Level of Employment } \\
\hline Senior Level & 34 \\
\hline Middle Level & 129 \\
\hline Bottom Level & 37 \\
\hline \multicolumn{2}{|l|}{ Years of Experience } \\
\hline $1-5$ years & 33 \\
\hline $6-10$ years & 116 \\
\hline $11-15$ years & 43 \\
\hline More than 16 years & 8 \\
\hline \multicolumn{2}{|l|}{ Accounting System that Currently Use } \\
\hline QuickBooks & 82 \\
\hline Saga 50 & 19 \\
\hline MYJOB & 12 \\
\hline ACCPAC & 18 \\
\hline SAP & 65 \\
\hline Other & 4 \\
\hline
\end{tabular}

Source: Survey Data 2020

Table 3 shows the reliability test and mean and standard deviation values of each variable. The reliability of the instrument was measured using Cronbach's Alpha value. It measures the internal consistency of the instrument 
based on the average inter-item correlation. The recommended value of 0.7 is used as a cut-off of reliabilities (George \& Mallery, 2003). Cronbach's Alpha values of the variables are shown in Table 3 , which suggests that the internal reliability of each variable is at a satisfactory level.

According to the research objective, as per Table 3, the researcher has tested mean and standard deviation values of each variable to formulate levels, respectively. The level of the human factor, technological factor, and environmental factor on Cloud-Based Accounting adoption was at a high level. The level of organisational factor on Cloud-Based Accounting adoption was at a moderate level.

'Table 3: Cronbach’s Alpha Value and Mean and Standard Deviation for Variables

\begin{tabular}{lccc}
\hline \multicolumn{1}{c}{ Variable } & $\begin{array}{c}\text { Cronbach's Alpha } \\
\text { Value }\end{array}$ & Mean & $\begin{array}{c}\text { Standard } \\
\text { Deviation }\end{array}$ \\
\hline $\begin{array}{l}\text { Human Factors } \\
\text { Innovativeness of senior }\end{array}$ & 0.744 & 4.06 & 0.574 \\
executives & & 3.99 & 0.630 \\
$\quad$ IT capability of staff & 0.732 & 4.15 & 0.699 \\
Technological Factors & & 3.54 & 0.303 \\
$\quad$ IT infrastructure & 0.770 & 4.12 & 0.631 \\
$\quad$ Compatibility & 0.733 & 3.86 & 0.666 \\
$\quad$ Complexity & 0.858 & 1.91 & 0.736 \\
$\quad$ Perceived value & 0.887 & 4.12 & 0.716 \\
Organisational factors & & 3.46 & 0.500 \\
$\quad$ Relative advantage & 0.701 & 3.97 & 0.640 \\
$\quad$ Top management support & 0.703 & 4.19 & 0.696 \\
$\quad$ Perceived cost & 0.849 & 2.04 & 0.836 \\
Environmental Factors & & 4.12 & 0.697 \\
$\quad$ Competitive pressure & 0.703 & 4.12 & 0.697 \\
CBA Adoption & 0.762 & & \\
\hline
\end{tabular}

Source: Survey Data 2020

The bivariate analysis procedures involve simultaneous analysis of data measured on variables to tests whether the relationship between two variables is linear. 
Table 4: Correlation Coefficient between Variables and Adoption of CBA

\begin{tabular}{|c|c|}
\hline Variable/Dimensions & Pearson Correlation (r) \\
\hline Innovativeness of senior executives & $\begin{array}{c}0.562^{* * * *} \\
(0.000)\end{array}$ \\
\hline IT capability of staff & $\begin{array}{c}0.760^{* * *} \\
(0.000)\end{array}$ \\
\hline Human factor & $\begin{array}{c}0.748^{* * * *} \\
(0.000)\end{array}$ \\
\hline IT Infrastructure & $\begin{array}{l}0.747^{* * *} \\
(0.000)\end{array}$ \\
\hline Compatibility & $\begin{array}{c}0.288^{* * *} \\
(0.000)\end{array}$ \\
\hline Complexity & $\begin{array}{c}-0.704^{* * * *} \\
(0.000)\end{array}$ \\
\hline Perceived value & $\begin{array}{c}0.827^{* * *} \\
(0.000)\end{array}$ \\
\hline Technological Factor & $\begin{array}{c}0.687^{* * *} \\
(0.000)\end{array}$ \\
\hline Relative advantage & $\begin{array}{l}0.645^{* * *} \\
(0.000)\end{array}$ \\
\hline Top management support & $\begin{array}{c}0.763^{* * * *} \\
(0.000)\end{array}$ \\
\hline Perceived cost & $\begin{array}{l}-0.012 \\
(0.870)\end{array}$ \\
\hline Organisational Factor & $\begin{array}{c}0.643^{* * *} \\
(0.000)\end{array}$ \\
\hline Competitive pressure & $\begin{array}{c}0.445^{* * *} \\
(0.000)\end{array}$ \\
\hline Environmental factor & $\begin{array}{c}0.445^{* * *} \\
(0.000)\end{array}$ \\
\hline
\end{tabular}

Significance level is indicated by ${ }^{* * *, * *, *}$ for $1 \%, 5 \%$ and $10 \%$ respectively

Significance levels are shown in parentheses

Source: Survey Data 2020

In the multiple regression analysis, there is a single dependent variable and multiple independent variables. In this study, Table 5 indicates that innovativeness of senior executives, IT capability of staff, IT infrastructure, compatibility, complexity, perceived value, relative advantage, and top management support, perceived cost significantly impact Cloud-Based Accounting adoption while competitive pressure is not significantly impacting on CBA adoption in Sri Lanka at 5\% significance level. 
Table 5: Regression

\begin{tabular}{|c|c|c|c|}
\hline Independent Variables & $\begin{array}{l}\text { Dependent Variable } \\
\text { Separate Regression }\end{array}$ & VIF & $1 / \mathrm{VIF}$ \\
\hline (Constant) & $\begin{array}{c}1.241^{* * *} \\
(0.000) \\
{[0.252]}\end{array}$ & & \\
\hline Innovativeness of senior executives & $\begin{array}{l}0.070^{* *} \\
(0.036) \\
{[0.033]}\end{array}$ & 1.620 & 0.617 \\
\hline IT capability of staff & $\begin{array}{l}0.091^{* *} \\
(0.047) \\
{[0.046]}\end{array}$ & 3.781 & 0.264 \\
\hline IT infrastructure & $\begin{array}{l}0.097^{* *} \\
(0.044) \\
{[0.048]}\end{array}$ & 3.415 & 0.293 \\
\hline Compatibility & $\begin{array}{l}0.060^{* *} \\
(0.028) \\
{[0.027]}\end{array}$ & 1.223 & 0.817 \\
\hline Complexity & $\begin{array}{c}-0.076^{* *} \\
(0.034) \\
{[0.036]}\end{array}$ & 2.561 & 0.390 \\
\hline Perceived value & $\begin{array}{c}0.230^{* * * *} \\
(0.000) \\
{[0.045]}\end{array}$ & 3.951 & 0.253 \\
\hline Relative advantage & $\begin{array}{l}0.075^{* *} \\
(0.042) \\
{[0.036]}\end{array}$ & 2.023 & 0.492 \\
\hline Top management support & $\begin{array}{c}0.110^{* * *} \\
(0.008) \\
{[0.041]}\end{array}$ & 3.023 & 0.331 \\
\hline Perceived cost & $\begin{array}{c}-0.041^{* *} \\
(0.040) \\
{[0.020]}\end{array}$ & 1.020 & 0.981 \\
\hline Competitive pressure & $\begin{array}{c}0.052^{*} \\
(0.073) \\
{[0.029]}\end{array}$ & 1.522 & 0.653 \\
\hline $\mathrm{R}$ & 0.898 & & \\
\hline $\mathrm{R}^{2}$ & 0.806 & & \\
\hline Adjusted $\mathrm{R}^{2}$ & 0.795 & & \\
\hline $\mathrm{F}$ & $\begin{array}{c}78.345^{* * *} \\
(0.000)\end{array}$ & & \\
\hline
\end{tabular}

Significance level is indicated by ${ }^{* * *},{ }^{* *},{ }^{*}$ for $1 \%, 5 \%$ and $10 \%$ respectively.

Significance levels are shown in parentheses and standard errors are reported in square brackets.

Source: Survey Data 2020

As per the result of ANOVA (Table 5), the regression model was significant $(\mathrm{F}=78345 ; \mathrm{p}=0.000)$. According to Table 5 , the score of $\mathrm{R}^{2}$ indicates that innovativeness of senior executives, IT capability of staff, IT infrastructure, compatibility, complexity, perceived value, relative advantage, top management support, perceived cost, and competitive pressure 
(independent variable) explains approximately $80.6 \%$ of the variance in CBA adoption (dependent variable).

According to the coefficient result, the regression model can be express as follows;

$\mathrm{Y}=\alpha+\beta 1 \mathrm{ISE}+\beta 2 \mathrm{ITS}+\beta 3 \mathrm{ITI}+\beta 4 \mathrm{CB}+\beta 5 \mathrm{CX}+\beta 6 \mathrm{PV}+\beta 7 \mathrm{RA}+\beta 8$ $\mathrm{TMS}+\beta 9 \mathrm{PC}+\beta 10 \mathrm{CP}+\mathrm{e}$

$\mathrm{Y}=0.070 \mathrm{ISE}+0.091 \mathrm{ITS}+0.097 \mathrm{ITI}+0.060 \mathrm{CB}-0.076 \mathrm{CX}+0.230 \mathrm{PV}+$ $0.075 \mathrm{RA}+0.110 \mathrm{TMS}-0.041 \mathrm{PC}+0.052 \mathrm{CP}$

Where, CBA adoption $=0.070$ Innovativeness of senior executives + 0.091 IT capability of staff +0.097 IT infrastructure +0.060 Compatibility 0.076 Complexity +0.230 Perceived value +0.075 Relative advantage +0.110 Top management support -0.041 Perceived cost +0.052 competitive pressure

According to the model, the $\beta$ value indicates when innovativeness of senior executives, IT capability of staff, IT infrastructure, compatibility, perceived value, relative advantage, top management support, and competitive pressure increase by one unit CBA adoption increase by 0.070, 0.091, 0.097, $0.060,0.325,0.230,0.075,0.110,0.052$ respectively. When complexity and perceived cost increase by one unit CBA adoption decrease by 0.076 and 0.041 , respectively.

Based on the results of the variance inflation factor (VIF), there is no multicollinearity among the independent variables. The VIF for all the independent variables is less than 10. Therefore, the model of this study is free from the multicollinearity problem. Based on the results of correlation and regression, hypotheses are accepted.

The level of perceived determinants of adoption of cloud-based accounting is discussed here. The level of human factor on CBA adoption was at a high level. According to the descriptive statistics, the results mean value shows as 4.06. The dimensions in the human variable, innovativeness of senior executives, and IT capability of staff also show a high value reflecting that opinion of accountants falls between partially high levels of agreement on the scale with mean values of 3.99, 4.15 respectively. Abdullah (2016) identified a high level in IT capability of staff in the study of CBA adoption. 
The level of the technological factor on CBA adoption was at a high level, and the average value shows as 3.54. The dimensions of technological variable, IT infrastructure, compatibility, and also perceived value show a high level of mean values $4.12,3.86$, and 4.12 accordingly while complexity shows a low level of mean value 1.91 in Sri Lanka, which have pointed out that opinion of accountants falls between high levels of agreeing points of the scale regarding the IT infrastructure, compatibility and perceived value of adopting CBA to companies while the opinion of accountants falls low level of the complexity of adopting CBA. Based on the findings of Abdullah (2016), compatibility shows a high level.

The level of the organisational factor on CBA adoption was at a moderate level mean value of 3.46. The dimensions of organisational variable, top management support, and relative advantage also show high level mean values of 4.19 and 3.97, as well as the perceived cost of 2.04, which shows a low level of CBA adopted in Sri Lanka. Abdullah (2016) stated that top management support (as well as a relative advantage shows a high level. The level of an environmental factor (competitive pressure) on CBA adoption was a high level of mean value 4.12. In the opinion of Abdullah (2016), Competitive pressure shows a high level.

In this study, there is a significant strong positive relationship between the human factor and CBA adoption. As claimed by Qirim (2008), it has proved that $\mathrm{CBA}$ adoption is positively related to the innovativeness of senior executives. There is a positive, significant relationship between training of employees in adopting organisations and the propensity with which technologies are adopted (Warren, 2004). As per the research findings, CBA adoption is significantly correlated with technological factors, and it shows a strong positive relationship with CBA adoption. There is extensive empirical evidence that perceived ease of use, which is the opposite of perceived complexity, is significant and positively related to usage intentions; thus, it reveals that complexity is negatively related to adoption. Sobhan (2019), Livera (2017), and Abdullah (2016) stated that complexity is negatively related to CBA adoption. Sobhan (2019) found that compatibility shows a positive relationship. As specified by Malak (2016), compatibility showed positive, significant associations between the adoptions of new technologies. The findings of Sharif (2015), a high level of compatibility positively motivate the organisation to adopt Information systems. 
The research findings reveal that CBA adoption is significantly correlated with organisational factors, and it shows a strong positive relationship with the adoption of CBA in Sri Lanka. Bassellier et al. (2003), revealed that there is a moderate positive relationship between top management support and adoption of CBA. The report of Abdullah (2016), showed a positive relationship between top management support and adoption of CBA. Rind et al. (2017), defined perceived cost have a negative correlation between adoption. In accordance with research findings, CBA adoption is significantly correlated with environmental factors (competitive pressure), although it shows a medium positive relationship with CBA adoption. Sobhan (2019) has found that increased competition has a positive relationship with CBA adoption in a company. Tweel (2012) revealed, environmental context factors positively related to IT decision-makers' intent to adopt CBA.

The results of multiple regression showed that the innovativeness of senior executives was found to have a positive impact on CBA adoption. In line with Qirim (2008), he revealed that CBA adoption is positively and significantly affected by the innovativeness of senior executives, and here, it was found that there was a significant impact of innovativeness of senior executives for the adoption of CBA. Tehrani (2013) found innovativeness positively affects the decision-making process of cloud adoption. Under the results of multiple regression, the IT capability of staff was found to have a positive impact on CBA adoption, and the result of the analysis allows for nonrejection of hypothesis two as the IT capability of staff significantly impacts CBA adoption This finding mostly matches with the findings of Al-Emran and Teo (2019), the theory that lowering knowledge barriers will facilitate the adoption of IS.

According to the results of multiple regression, infrastructure was found to have a positive impact on CBA adoption, and the result of the analysis allows for non-rejection of hypothesis three, as infrastructure significantly impacts CBA adoption. Alam et al. (2016), defined IT infrastructure significant impact on the adoption of CBA. As per the results of multiple regression, compatibility was found to have a positive impact on CBA adoption. The result of the analysis allows for non-rejection of hypothesis four as compatibility is significantly impacted by CBA adoption. Gutierrez et a. (2015) also found complexity is a significant factor in the adoption decision, in contrast to other innovation characteristics. Tehrani (2013) defined complexity as a negative impact on the decision-making process in cloud 
adoption. The results of multiple regression showed that the relative advantage was found to have a positive impact on CBA adoption. Gutierrez et al. (2015) defined relative advantage as a core indicator to the adoption of new information innovations and defined it as being the degree to which an organisational factor is perceived to provide a great benefit to an organisation, and researchers found that relative advantage as a significant factor that influences the decision to adopt CBA.

Top management support is extremely important for organisations looking to create a competitive environment whilst also providing the suitable resources required to adopt cloud services. Consequently, this factor is considered to have a significant impact on the adoption of CBA Gutierrez et al. (2015). Sobhan (2019) has found that increased competition has a positive relationship with IT implementation in a company.

With the latest advancement in the technology, accounting paradigm is in the move of embracing cloud-based accounting (Dimitriua \& Mateia, 2015). Irrespective of how important the current developments in the field of accounting, as far as the researcher has noticed, fewer researches have been done in this regard. The findings in this paper would enrich this stream of study by adding more value to the empirical evidence concerning cloud accounting awareness, perceived benefits, threats of cloud accounting, perceived barriers of adopting cloud-based accounting.

\section{CONCLUSION}

The primary aim of the study is to identify the perceived determinants of the adoption of cloud-based accounting in Sri Lanka. To achieve that aim, the researcher selected accountants in audit firms, manufacturing, finance, and other companies. As per the findings, most of the variables are high level with the adoption of CBA. The objective of this study is to examine the impact of the factors on the adoption of Cloud-Based Accounting in Sri Lanka. Factors, namely, innovativeness of senior executives, IT capability of staff, IT infrastructure, compatibility, perceived value, relative advantage, top management support, and competitive pressure positively impact the adoption of cloud-based accounting, whereas perceived cost and complexity negatively impact the adoption of cloud-based accounting in Sri Lanka.

Results of the study are supported by the Diffusion Theory and Theory 
of Reasoned Action. Further, the findings are consistent with the results of the previous studies such as Cong and Du (2010), Aleem and Sprott (2012), Christauskas and Miseviciene (2012), Dimitriua and Mateia (2015), Brandas et al. (2015), and Ozdemir and Elitas (2015).

The following recommendations are essential for top-level management to allocate adequate resources for the adoption of CBA. Organisational processes, people, time, information, and knowledge are all types of resources that should be properly managed and controlled by the organisation to enable the organisation to conceive and adopt a system that will improve its efficiency and effectiveness. Top management and accountants should play a proactive role in supporting CBA adoption in their organisations. They also have to allocate time and budget to train people on how to use and leverage the uses of CBA and on how to gain a competitive advantage through CBA. Training of staff is key during the adoption of CBA because it also helps in providing user information satisfaction. There is also a need for more consultation and involvement at all levels so that change initiatives can be readily accepted and adopted.

The top management needs to be convinced by the values and the strategic benefits of CBA to grant the required financial and non-financial support for CBA adoption as the companies that make the best use of these systems have the best chances to sustain a competitive advantage. Also, the organisation should pay much attention to establish a qualified and specialised IT team, and the organisation should prepare automatic performance indicators to enable them to interact with CBA step by step logically and critically as a starting point for successful adoption of CBA by employees'

Few limitations are identified in the study. This study faced several challenges as it only focused on the top level and middle-level accountants in Sri Lanka. Most respondents were very busy and hesitated to respond. Another limitation is that the sample size had to be restricted only to 200 accountants who are in Sri Lanka due to time limitations. The study also focuses on only ten factors as innovativeness of senior executives, IT capability of staff, IT infrastructure, compatibility, complexity, perceived value, relative advantage, top management support, perceived cost, and competitive pressure. Therefore, a qualitative in depth-study could be undertaken to gain more insight into the adoption of Cloud-based accounting in Sri Lanka. 
In this study, the researcher investigated critical perceived determinants of adoption of CBA in Sri Lanka. This study is a new thing, which was a knowledge gap in the Sri Lankan context to find out the impact of factors on CBA adoption in Sri Lanka. Contribution to the existing body of knowledge in terms of narrowing the research gap by exploring the factors that impact the adoption of CBA in Sri Lanka in the perception of Accountants. The novelty of this study is that it provides a holistic perspective of the list of research gaps and their effects adoption of CBA in Sri Lanka. In this context, various measures suggested in this study can be taken as guidance to reduce gaps in CBA adoption.

Finally, the results of the study provide implications for the organisation to adopt CBA and gain a better understanding of the critical variables that are significantly associated with the adoption of CBA. Findings may enable them to improve and gain more competitive advantages and minimising potential damaging factors for the adoption of CBA.

\section{REFERENCES}

Abdullah, A. (2016). A Knowledge Management Based Cloud Computing Adoption (Doctoral dissertation). Staffordshire University.

Ajzen, I., \& Fishbein, M. (1980). Understanding attitudes and predicting social behaviour. Englewood Cliffs, N.J: Prentice-Hall.

Alam, M. G., Masum, A. K., Beeh, L.-S., \& Hong, C. S. (2016). Critical Factors Influencing Decision to Adopt Human Resource Information System (HRIS) in Hospitals. PLoS ONE, 11(8). doi.org/10.1371/journal.pone.0160366

Al-Emran, M., \& Teo, T. (2019). Do knowledge acquisition and knowledge sharing really affect e-learning adoption? An empirical study. Education and Information Technologies. https://doi.org/10.1007/s10639-01910062-w

Aleem, A., \& Sprott, C. (2012). Let me in the cloud: analysis of the benefit and risk assessment of cloud platform. Journal of Financial Crime, 20(1), 6-24. 
Awa, H. O., Ukoha, O., \& Emeheta, B. C. (2016). Using T-O-E theoretical framework to study the adoption of ERP solution. Cogent Business \& Management, 3(1). doi:10.1080/23311975.2016.1196571

Banerjee, A., \& Chaudhury, S. (2010). Statistics without tears: Populations and samples. Industrial Psychiatry Journal, 19(1), 60-65. doi:10.4103/09726748.77642

Bassellier, G., Benbasat, I., \& Reich, B. (2003). The influence of business managers' IT competence on championing IT. Information Systems Research, 14, 317-336. doi:10.1287/isre.14.4.317.24899

Bhandayker, Y. R. (2019, February). A Study on the Research Challenges and Trends of Cloud Computing. International Journal of Multidisciplinary Research Review, 4(2). doi:10.5281/zenodo.2579238

Brandas, C., Megan, O., \& Didraga, O. (2015). Global perspective on accounting information systems: mobile and cloud approach. Procedia Economics and Finance, 20, 88-93.

Buyya, R., Chee, Y. S., \& Venugopa, S. (2008). Market-Oriented Cloud Computing: Vision, Hype, and Reality for Delivering IT Services as Computing Utilities. Paper presented at the $10^{\text {th }}$ IEEE International Conference on High Performance Computing and Communications.

Chong, Y., \& Nizam, I. (2017). The impact of accounting software on business performance. International Journal of Information System and Engineering, 6(1). doi:10.24924/ijise/2018.04/v6.iss1/01.26

Christaukas, C., \& Miseviciene, R. (2012). Cloud - Computing Based Accounting for small to Medium Sized Business. Engineering Economics, 23(1), doi:10.5755/j01.ee.23.1.1220

Cong, \& Du, y. \&. (2010). Cloud Computing, Accounting and Beyond. The CPA Journal, 80(1), 66-70.

Dandago, K. I., \& Rufai, A. S. (2014). Information Technology and Accounting Information System in the Nigeria Banking Industry. Asian Economic and Financial Review, 4(5), 655-670. 
DeLone, W. H., \& McLean, E. R. (2003, April 30). The DeLone and McLean Model of Information Systems Success: A Ten-Year Update. Journal of Management Information Systems, 19(4). doi:10.1080/07421222.2003.11045748

Dimitriua, O., \& Mateia, M. (2015). Cloud Accounting: A New Business Model in a Challenging Context. Procedia Economics and Finance, 32, 665-671.

Ebenezer, \& Antwi, O. (2014). Accounting in the cloud: how could computing can transform businesses: The Ghanaian perspective. Paper presented at International Conference on Global Business, Economics, Finance and Social Sciences, Chennai.

George, D., \& Mallery, P. (2003). SPSS for Windows step by step: A simple guide and reference ( $4^{\text {th }}$ ed.). Boston: Allyn \& Bacon.

Gutierrez, A., Elias, B., \& Ranald, L. (2015). Technological, organisational and environmental factors influencing managers' decision to adopt cloud computing in the UK. Journal of Enterprise Information Management, 28(6), 788-807. doi: 10.1108/JEIM-01-2015-0001

Isleem, M. (2003). Relationships of selected factors and the level of computer use for instructional purposes by technology education teachers in Ohio public schools: a statewide survey (Doctoral dissertation). The Ohio State University.

Livera, L. (2017). Cloud Based Accounting: The Perspective of Accounting Professionals of Sri Lanka (Unpublished undergraduate dissertation). University of Sri Jayewardenepura.

Malak, J. (2016). An Analysis of the Technological, Organisational, and Environmental Factors Influencing Cloud Adoption (Doctoral dissertation). Walden University.

Medlin, B. D. (2003). The factors that may influence a faculty member's decision to adopt electronic technologies in instruction (Doctoral dissertation). Virginia Polytechnic Institute and State University. 
Mihalache, A. S. (2011). Cloud Computing, Ovidius University Annal. Economic Sciences Series, XI (2), 782-787.

Mizuno, Y., \& Odake, N. (2015). A case study of progressive formation of Accounting Cloud Services in Japan. International Journal of Service Science, Management, Engineering, and Technology (IJSSMET), 6(1). doi:10.4018/ijssmet.2015010101

Ozdemir, S., \& Elitas, C. (2015). The risk of cloud computing in accounting field and the solution offers: the case of Turkey. Journal of Business Research Turk, 43-59.

Qirim, A. (2008). The adoption of e Commerce communications and applications technologies in small businesses in New Zealand. Electronic Commerce Research and Applications.

Rao, T. M., Jyostna, T., \& Sivani, M. (2012). Impact of Cloud Accounting: Accounting Professional's Perspective. IOSR Journal of Business and Management, 33-59.

Rind, M. M., Hyder, M., Saand, A. S., Alzabi, T., Nawaz, H., \& Ujan, I. (2017). Impact Investigation of perceived cost and perceived risk in mobile commerce: analytical study of Pakistan. International Journal of Computer Science and Network Security, 17(11), 124-130.

Robert, A. T., \& Agada, A. B. (2016). Effect of Accounting Information System on Financial Reporting Quality: A review of Theories and Empirical Works.

Rogers, E. (2003). Diffusion of innovations (5 ${ }^{\text {th }}$ ed.). New York: Free Press.

Shareef, M., Kumar, V., Kumar, U., \& Hasin, A. (2009). Theory of Planned Behaviour and Reasoned Action in Predicting Technology Adoption Behaviour. In Y. K. Dwivedi, B. Lal, M. D. Williams, S. L. Schneberger, \& M. Wade (Eds.), Handbook of Research on Contemporary Theoretical Models in Information Systems. IGI Global. http://doi:10.4018/978-160566-659-4.ch031 
Sharif, M. H. (2015). Social media adoption and impact in Australian Local Government (Doctoral dissertation). Business School, University of Adelaide.

Sharma, P. (2016). An Empirical Study on Measuring Awareness of Cloud Accounting. International Journal of Science and Research, 7(11), 13851393.

Shy, C. M. (1997). The failure of academic epidemiology: witness for the prosecution. American Journal of Epidemiology, 145(6), 479-484

Sobhan, R. (2019). The Concept of Cloud Accounting and its Adoption in Bangladesh. International Journal of Trend in Scientific Research and Development (IJTSRD), 3(4). doi:10.31142/ijtsrd24031

Strauss, E., Kristandl, G., \& Quinn, M. (2014). The effects of cloud technology on management accounting and decision making. CIMA Research Executive Summary Series, 10(6).

Tehrani, S. R. (2013). Factors Influencing the Adoption of Cloud Computing by Small and Medium-Sized Enterprises (SMEs) (Master's thesis). Ryerson University.

Tweel, A. (2012). Examining the relationship between Technological, Organisational, and Environmental Factors and Cloud Computing Adoption (Doctoral dissertation). Northcentral University, Arizona.

Waga, D., Makori, E., \& Rabah, K. (2014). Utilization of Cloud Computing in Education and Research to the Attainment of Millennium Development Goals and Vision. Universal Journal of Educational, 2(2), 193-199.

Warren, M. (2004). Farmers Online: Drivers and Impediments in Adoption of Internet in UK Agricultural Businesses. Journal of Small Business and Enterprise Development, 11(3), 371-381. doi:10.1108/14626000410551627 